Original Research

\title{
Effect of Soil Polluted with Petroleum-Derived Substances during Bioremediation on the Occurrence of Collembola and Acarina
}

\author{
Janina Gospodarek*, Milena Rusin \\ Department of Microbiology and Biomonitoring, University of Agriculture, Krakow, Poland
}

Received: 7 October 2019

Accepted: 15 November 2019

\begin{abstract}
The research aimed at investigating the effect of soil contamination with various petroleum-derived substances (PDSs, e.g., spent engine oil, diesel fuel, and petrol) on springtail (Collembola) and mite (Acarina) occurrence over 28 months from the moment of pollution. We also assessed the effect of the bioremediation process supported by ZB-01 preparation on the process of soil settlement by the above-mentioned invertebrates. We tried to determine whether the occurrence and activity of these organisms may be useful as a bioindicator or monitoring tool for assessing PDS presence in the soil and speed of remediation process (both natural and supported). A combined method, i.e., pitfall trapping and analysis of soil samples, was used for assessing the presence of Collembola and Acarina. Considering the investigated PDSs, petrol revealed the shortest (about a year) negative effect on Collembola presence on the soil surface (measured by pitfall trapping), whereas it was visible for the longest time (2 years) for diesel fuel. Although initiating a bioremediation process using ZB-01 preparation on soil polluted with petrol (in the first year) and diesel fuel (in the second) resulted in a significant increase in Collembola activity on the soil surface, it limited this parameter in soil contaminated with engine oil and in the control soil (in the second and third years of the experiment). Both diesel fuel and engine oil revealed a strong negative effect on the occurrence of springtails and mites in soil (soil sample analysis) perceptible even after 28 months from the moment of soil pollution. At the same time, a visible positive response to applied bioremediation supported by biopreparation ZB-01 was registered. Analysis of soil samples polluted with PDSs for springtail and mite presence may be a potentially useful indicator for assessing the degree of soil self-cleaning, since a perceptible response was noticed, dependent both on the PDS and the course of the supported bioremediation process.
\end{abstract}

Keywords: oil derivatives, soil, bioremediation, Collembola, Acarina

*e-mail: rrjgospo@cyf-kr.edu.pl 


\section{Introduction}

Soil pollution with petroleum-derived substances (PDSs) entails a strong negative effect on both its physicochemical properties $[1,2]$ and biological activity [3-7], as well as causing far-reaching changes in organisms indirectly exposed to these pollutants (e.g., herbivores) [8-10]. The components that are especially dangerous to the environment are polycyclic aromatic hydrocarbons (PAHs) [11]. Efficient methods for their safe neutralization are still being sought through bioaugmentation or adding surfactants [12, 13], optimization of fertilization [14], rhizoremediation [15] or electrobioremediation [16]. Among the methods mentioned above, the use of specially selected microorganisms breaking down organic compounds gives beneficial results in cleaning soils contaminated mainly by medium and low PAH concentrations [17].

Among microinvertebrates, Collembola and Acarina are mentioned as potential bioindicators of changes in the soil environment, mainly due to their common occurrence and the role they play in the processes of matter cycling in nature [18-20]. Collembola are characterized by high sensitivity to soil pollution with heavy metals showing lower densities in the soils with higher metal concentrations [21, 22]. On the other hand, oribatid mite communities (which dominate among invertebrates inhabiting the topsoil) display a great variety of responses to heavy metals [23]. Features such as fertility and survival rate of Collembola are mentioned as greatly sensitive indicators of soil contamination with PAHs [24, 25]. We also investigated Collembola and Acarina occurrence in soils polluted to various degrees with PAHs [26, 27]. The mortality of springtails were also used as one of the tests for assessing the ecotoxicological usability of various bioremediation techniques of soils contaminated with oil derivatives, indicating a rapid reduction of toxicity [28]. Among ecological indicators, abundance and density of invertebrates are regarded as features that reflected the trend of soil chemical and physical characteristics to a greater extent than taxa richness [22]. Some researchers have also suggested that the ratio between the number of mites and collembolans is a useful indicator for the assessment of human activity effect upon the soil environment. The high value of this indicator suggests high soil quality [29].

So far little attention has been paid to a potential application of the analysis of the above-mentioned invertebrate groups occurrence for the assessment of the rate of natural bioremediation and microbial biopreparation-supported process on soils polluted with PDSs [30]. Scientific literature provides the results of research into the effects of PDSs on different elements of the environment; however, they usually pertain to soil environmental changes occurring soon after contamination. There is a lack of data on the more long-term consequences of these pollutants, especially in field conditions. On the other hand, in the available literature we can find data on the impact of distant in time petroleum soil contamination on soil fauna [27]. However, these in turn do not take into account the effect immediately after pollution. It would be interesting to study how over a longer period of time, starting from the moment of pollution, the possibilities of soil settlement by mentioned soil fauna in field-realistic conditions changed. It is also worth emphasizing that the analysis of the occurrence of springtails and mites has not yet been considered as a simple way to assess the speed of self-cleaning soil polluted with PDSs and subjected to bioremediation. The latest research conducted in sub-Antarctic areas indicates the usefulness of assessing the occurrence of native springtails and mites in the environmental risk assessment of soils contaminated with petroleum hydrocarbons [31, 32].

The aim of our paper was to determine: a) the effect of soil contamination with various PDSs (petrol, diesel fuel and used engine oil) on springtail (Collembola) and mite (Acarina) occurrence over 28 months from the moment of pollution and $b$ ) the effect of bioremediation process supported by ZB-01 microbial preparation on the process of soil settlement by the above-mentioned invertebrates. We sought to determine whether the occurrence and activity of these organisms may be useful as a bioindicator or monitoring tool for assessing PDS presence in the soil and speed of remediation process (both natural and supported). We also tried to compare two methods of analyzing microfauna occurrence, i.e., pitfall trapping and soil sample analysis.

\section{Material and Methods}

The investigations were conducted at the Experimental Station of the University of Agriculture in Mydlniki near Krakow (505'5,04'N 1951'13,47’E). In autumn 2009 indigenous soil (detailed description in the earlier paper [33]) was placed in $1 \mathrm{~m}^{3}$ containers with maintained natural layers arrangement. The containers were then dug into the soil so that their upper area was on the same level with the surrounding soil. Additionally, the upper section of the container sides was perforated to enable the invertebrates free penetration of the polluted soil. Perforated plastic tubes were also placed in all containers (every $30 \mathrm{~cm}, 4$ pieces per container) for proper soil aeration in the gravitation system, which is a prerequisite for proper course of the bioremediation process. The soil in containers was left untouched for 8 months in order to allow it to restore its natural biological efficiency. Subsequently, in June 2010 the soil in containers was polluted (by pouring) with the following oil derivatives: petrol, diesel oil and used engine oil in the amounts equal to $6000 \mathrm{mg}$ of fuel $\cdot \mathrm{kg}^{-1}$ d.m. of soil (i.e., a typical oil derivative concentration in medium-polluted soils). Four objects were identified: 1. Control - unpolluted soil, 
2. Soil with a simulated petrol leak (P), 3. Soil with a simulated diesel fuel (DF) leak and 4. Soil with a simulated used engine oil leak (EO). A week later half of the containers were subjected to bioremediation. The process of oil derivatives bioremediation was initiated and continued by adding ZB-01 preparation to the soil, which was especially prepared for this purpose and contained selected procarytotic microorganisms, mainly bacteria: Stenotrophomonas, Pseudomonas, Moraxella, Acinetobacter, Alcaligenes, Ochrobactrum, Comamonas, Burkholderia, Corynebacterium, and Oligella. The treatment was applied by sprinkling, maintaining $60 \%$ of soil sorption moisture. Prior to the biopreparation application, a multicomponent fertilizer (Azofoska; 13.6\% N, 2.8\% P and 15.8\% K) dosed 100 $\mathrm{g}$ per container was applied to the soil surface in the containers that were intended to undergo this treatment. The activity of breakdown of organic and aromatic compounds contained in oil derivative pollutants by the suggested biopreparation was verified and proved in the environmental practice, as well as published [6]. After a year (in spring 2011), bioremediation treatment was repeated following the same procedure as in 2010 .

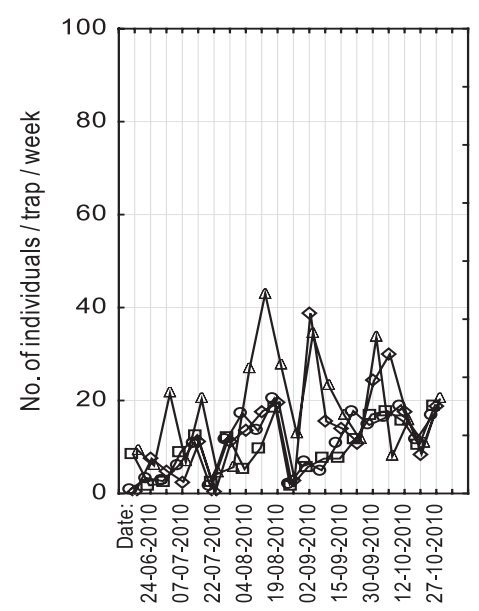

OR

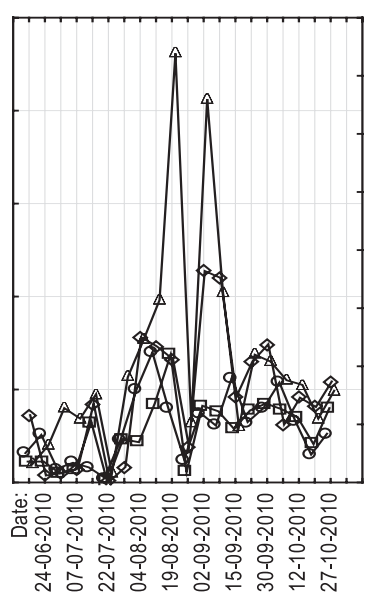

$\mathrm{R}$

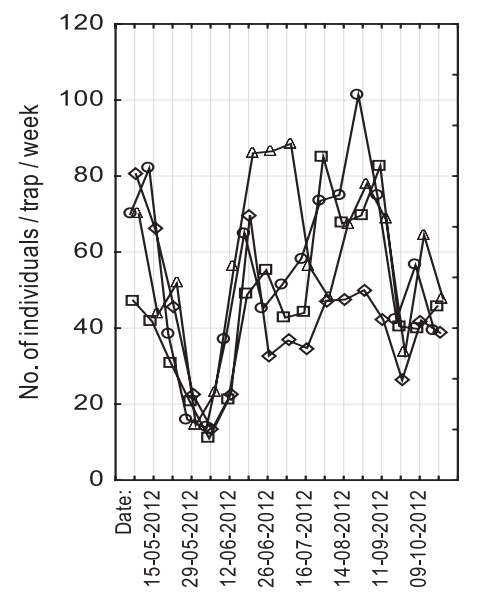

OR

The whole experiment was conducted in 4 replications according to randomized block design.

A combined method, i.e., pitfall trapping and analysis of soil samples, was used to assess the presence of Collembola. The application of this method using Collembola is recommended in large-scale biodiversity assessments since it allows us to obtain a more complete picture of the collembolan community on site than either method alone [34]. One pitfall trap $\left(0.9 \mathrm{dm}^{3}\right.$ jar dug even with the soil level and protected against atmospheric precipitation with a plastic roof) was placed in the central point of each container. The traps were emptied once a week during the periods from June to October 2010, and from May to October 2011 and 2012. Moreover, soil samples were collected once a month during growing season, thoroughly viewed under a binocular and identified fauna (Acarina and Collembola) was counted and classified. A split corer was used for sample extraction (according to ISO standard 23611-2-2006 [35]). The diameter and depth of the sample were $5 \mathrm{~cm}$ and $15 \mathrm{~cm}$, respectively. The volume of a sample was $294.52 \mathrm{~cm}^{3}$. Soil was sampled separately from three evenly distributed places in

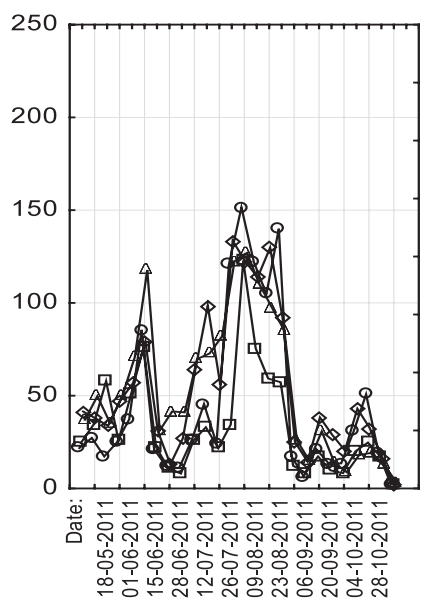

OR

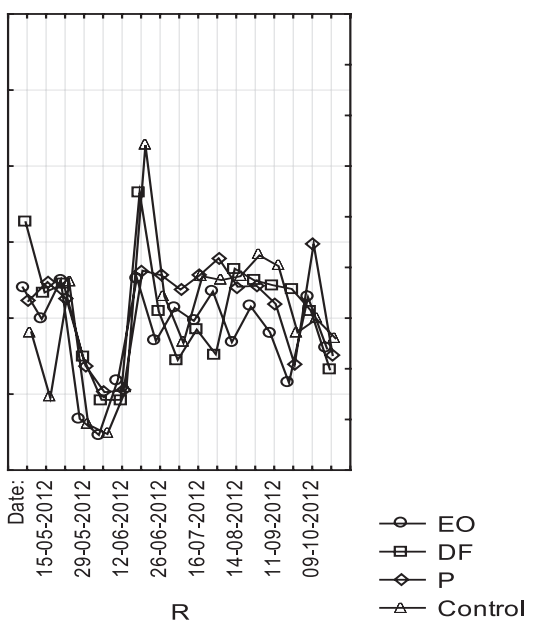

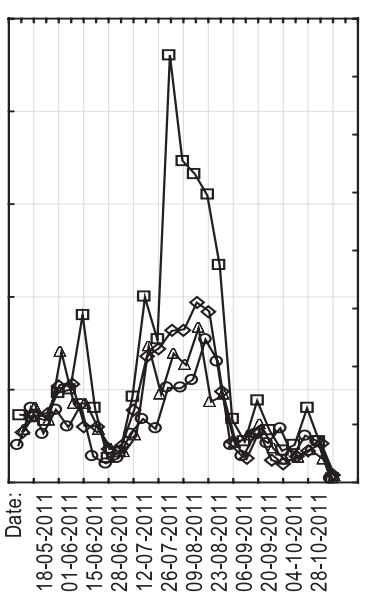

$R$

Fig. 1. Occurrence dynamics of Collembola trapped using pitfall traps in the years 2010, 2011 and 2012. EO - soil contaminated with used engine oil. DF - soil contaminated with diesel fuel. P - soil contaminated with petrol. Control - unpolluted soil. 0R - series without ZB-01, R - series with ZB-01. 
each container. The total sample from each container was $\approx 300 \mathrm{~g}$ of soil. In addition, the ratio between the total numbers of Acarina and Collembola (A/C) was calculated due to the usefulness of the above-mentioned bioindicator for soil quality assessment as confirmed by the literature of the subject [22].

Statistical computations were made using Statistica 13.1 PL software. ANOVA two-way analysis were carried out. Means were diversified using Fisher's LSD test at significance level $\alpha=0.05$.

\section{Results and Discussion}

The dynamics of springtails occurrence on the soil surface (measured by pitfall trapping) in individual years of investigations indicates their peak activity in summer months (July-August) (Fig. 1). A similarly dynamic occurrence of these invertebrates was registered also in previous investigations [36, 37]. Pouring the PDSs to the soil caused a considerable decline in the number of springtails caught using this method (Table 1). Differences in comparison with the control were particularly visible under conditions of soil polluted with engine oil. A decrease in the number of Collembola caught in the soils polluted with petrol and engine oil was apparent even 12 months after soil contamination. On the other hand, a negative effect of diesel fuel remained even for 2 years after soil pollution. Bioremediation of petrol-polluted soil in the initial period (2010 season) contributed to an increase in springtail activity, and a similar effect was registered also in 2011 for the soil polluted with diesel fuel (Table 1, Fig. 2). On the other hand, regarding the soil polluted with engine oil and control soil, bioremediation limited Collembola activity in 2011 and 2012 seasons. This negative effect was also observed in the second season of investigations (2011) in soil polluted with petrol.

The analysis of the soil samples for Collembola presence (second method) revealed that they were almost absent in the soil polluted with PDSs during the first season of research (2010) (Table 2). Single specimens were registered only 4 months after contamination in the soil polluted with engine oil, but later, until the end of research (i.e., 28 months from the time of pollution) their presence was not spotted even once in the analyzed soil samples. Similarly, in the object where the soil was contaminated with diesel fuel, springtail presence was registered only

Table1. Occurrence of Collembola trapped using pitfall traps in individual months after soil contamination.

\begin{tabular}{|c|c|c|c|c|c|c|c|c|}
\hline \multirow{3}{*}{$\begin{array}{l}\text { Number of months } \\
\text { from the moment of soil } \\
\text { contamination }\end{array}$} & \multicolumn{8}{|c|}{ Collembola [No. of individuals / trap / month] } \\
\hline & \multicolumn{2}{|c|}{ Control } & \multicolumn{2}{|c|}{ Petrol } & \multicolumn{2}{|c|}{ Diesel fuel } & \multicolumn{2}{|c|}{ Engine oil } \\
\hline & $0 \mathrm{R}$ & $\mathrm{R}$ & $0 \mathrm{R}$ & $\mathrm{R}$ & $0 \mathrm{R}$ & $\mathrm{R}$ & OR & $\mathrm{R}$ \\
\hline 1 & $43.50^{c *}$ & $41.75^{\mathrm{bc}}$ & $15.25^{\mathrm{abc}}$ & $21.00^{\mathrm{abc}}$ & $21.25^{\mathrm{abc}}$ & $13.75^{\mathrm{ab}}$ & $13.00^{\mathrm{a}}$ & $23.83^{\mathrm{abc}}$ \\
\hline 2 & $51.58^{\mathrm{ab}}$ & $74.42^{\mathrm{b}}$ & $36.50^{\mathrm{a}}$ & $51.83^{\mathrm{ab}}$ & $32.00^{\mathrm{a}}$ & $31.42^{\mathrm{a}}$ & $41.25^{\mathrm{a}}$ & $33.50^{\mathrm{a}}$ \\
\hline 3 & $11750^{c}$ & $227.08^{\mathrm{d}}$ & $79.00^{\mathrm{abc}}$ & $109.00^{\mathrm{bc}}$ & $35.75^{\mathrm{a}}$ & $63.25^{\mathrm{abc}}$ & $42.50^{\mathrm{ab}}$ & $64.00^{\mathrm{abc}}$ \\
\hline 4 & $85.00^{\mathrm{bc}}$ & $106.25^{\mathrm{c}}$ & $64.75^{\mathrm{ab}}$ & $118.25^{\mathrm{c}}$ & $43.75^{\mathrm{a}}$ & $59.33^{\mathrm{ab}}$ & $48.25^{\mathrm{a}}$ & $63.75^{\mathrm{ab}}$ \\
\hline 5 & $54.50^{\mathrm{a}}$ & $76.50^{\mathrm{a}}$ & $75.25^{\mathrm{a}}$ & $68.75^{\mathrm{a}}$ & $62.75^{\mathrm{a}}$ & $54.00^{\mathrm{a}}$ & $63.75^{\mathrm{a}}$ & $51.25^{\mathrm{a}}$ \\
\hline 11 & $243.00^{c}$ & $213.25^{\mathrm{bc}}$ & $217.25^{\mathrm{bc}}$ & $206.50^{\mathrm{bc}}$ & $193.50^{\mathrm{abc}}$ & $203.75^{\mathrm{abc}}$ & $128.25^{\mathrm{a}}$ & $156.00^{\mathrm{ab}}$ \\
\hline 12 & $231.50^{c}$ & $105.00^{\mathrm{a}}$ & $149.75^{b}$ & $99.00^{\mathrm{ab}}$ & $117.25^{\mathrm{ab}}$ & $159.50^{\mathrm{b}}$ & $129.25^{\mathrm{ab}}$ & $79.00^{\mathrm{a}}$ \\
\hline 13 & $347.00^{\mathrm{bc}}$ & $215.25^{\mathrm{ab}}$ & $352.00^{\mathrm{bc}}$ & $261.75^{\mathrm{ab}}$ & $115.00^{\mathrm{a}}$ & $453.25^{c}$ & $216.25^{\mathrm{ab}}$ & $140.50^{\mathrm{a}}$ \\
\hline 14 & $445.50^{\mathrm{ab}}$ & $258.25^{\mathrm{a}}$ & $483.00^{\mathrm{ab}}$ & $343.00^{\mathrm{a}}$ & $327.00^{\mathrm{a}}$ & $645.00^{\mathrm{b}}$ & $535.74^{\mathrm{ab}}$ & $269.00^{\mathrm{a}}$ \\
\hline 15 & $68.50^{\mathrm{a}}$ & $85.67^{\mathrm{a}}$ & $102.00^{\mathrm{a}}$ & $62.00^{\mathrm{a}}$ & $43.75^{\mathrm{a}}$ & $111.00^{\mathrm{a}}$ & $54.75^{\mathrm{a}}$ & $90.50^{\mathrm{a}}$ \\
\hline 16 & $53.25^{\mathrm{a}}$ & $46.50^{\mathrm{a}}$ & $94.00^{\mathrm{a}}$ & $56.50^{\mathrm{a}}$ & $64.25^{\mathrm{a}}$ & $84.50^{\mathrm{a}}$ & $102.75^{\mathrm{a}}$ & $64.00^{\mathrm{a}}$ \\
\hline 23 & $179.75^{\mathrm{ab}}$ & $116.50^{\mathrm{a}}$ & $214.75^{\mathrm{b}}$ & $166.50^{\mathrm{ab}}$ & $140.17^{a b}$ & $191.00^{\mathrm{ab}}$ & $206.50^{\mathrm{b}}$ & $144.00^{\mathrm{ab}}$ \\
\hline 24 & $251.50^{\mathrm{b}}$ & $162.25^{\mathrm{ab}}$ & $138.58^{\mathrm{a}}$ & $145.25^{\mathrm{a}}$ & $136.00^{\mathrm{a}}$ & $151.75^{\mathrm{a}}$ & $160.75^{\mathrm{ab}}$ & $117.50^{\mathrm{a}}$ \\
\hline 25 & $192.50^{c}$ & $134.50^{\mathrm{abc}}$ & $118.75^{\mathrm{ab}}$ & $154.50^{\mathrm{abc}}$ & $171.75^{\mathrm{bc}}$ & $96.50^{\mathrm{a}}$ & $183.33^{\mathrm{bc}}$ & $128.92^{\mathrm{abc}}$ \\
\hline 26 & $145.25^{\mathrm{cd}}$ & $107.50^{\mathrm{abc}}$ & $97.50^{\mathrm{ab}}$ & $96.75^{\mathrm{ab}}$ & $137.17^{\mathrm{bcd}}$ & $103.00^{\mathrm{ab}}$ & $176.25^{\mathrm{d}}$ & $76.67^{\mathrm{a}}$ \\
\hline 27 & $102.00^{\text {cde }}$ & $89.92^{\mathrm{a}-\mathrm{d}}$ & $68.58^{\mathrm{ab}}$ & $71.50^{\mathrm{abc}}$ & $123.17^{\mathrm{e}}$ & $96.33^{\mathrm{b}-\mathrm{e}}$ & $117.00^{\mathrm{de}}$ & $59.25^{\mathrm{a}}$ \\
\hline 28 & $112.25^{\mathrm{b}}$ & $74.42^{\mathrm{a}}$ & $80.75^{\mathrm{ab}}$ & $89.75^{\mathrm{ab}}$ & $85.50^{\mathrm{ab}}$ & $68.50^{\mathrm{a}}$ & $95.75^{\mathrm{ab}}$ & $77.50^{\mathrm{a}}$ \\
\hline
\end{tabular}

*Means in lines marked with the same letters do not differ significantly according to LSD test at $\alpha=0.05$; factors contamination $\mathrm{x}$ remediation. $0 \mathrm{R}$ - series without ZB-01, R - series with ZB-01. 

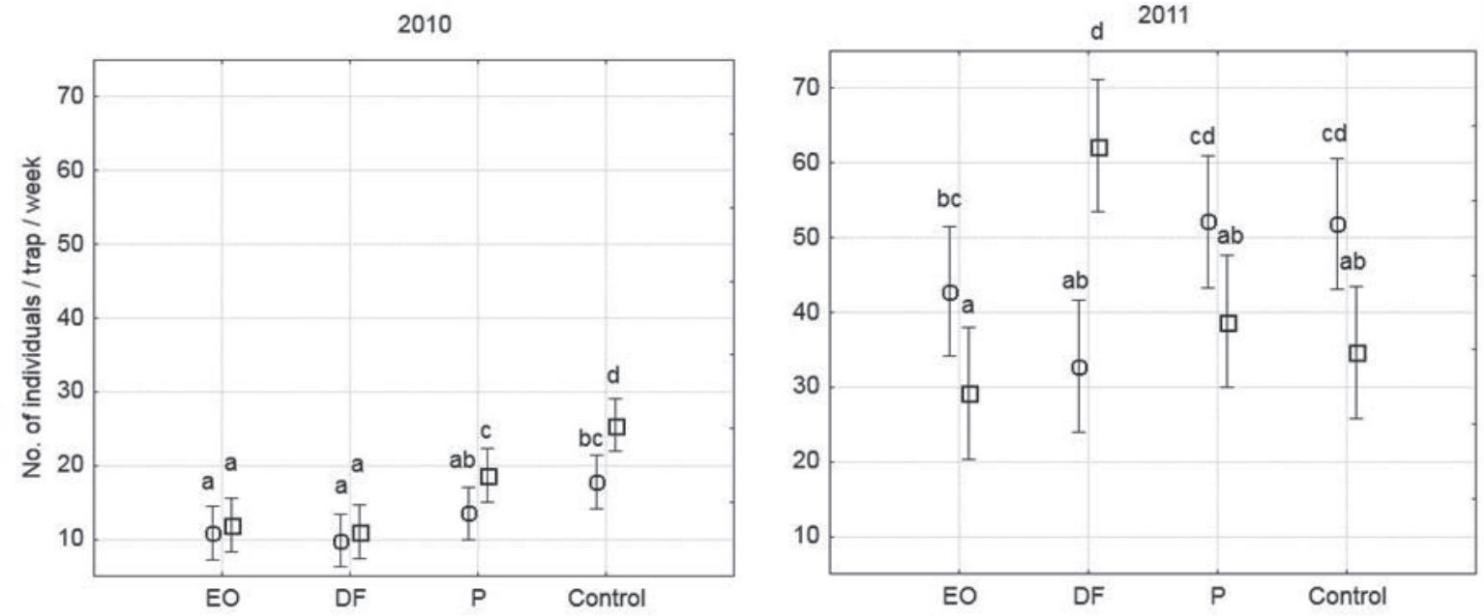

2012

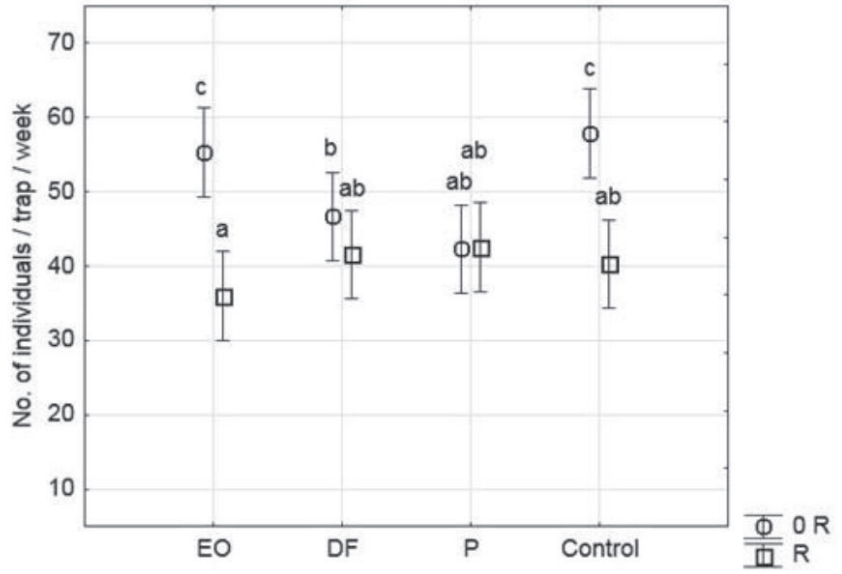

Fig. 2. Occurrence of Collembola trapped using pitfall traps in the years 2010, 2011, and 2012. Explanation as in Fig. 1. Means marked with the same letters do not differ significantly according to LSD test at $\alpha=0.05$; factors contamination x remediation. 工 Mean \pm 0.95 confidence interval.

once - in the $25^{\text {th }}$ month after contamination. The earliest appearances of these invertebrates, in similar number as in the control, were spotted in the object with soil contaminated with petrol $\left(11^{\text {th }}\right.$ months after contamination). It may be explained by a great number of volatile components in petrol, which quickly evaporated, as demonstrated by Kireeva et al. [24], considerably diminishing the oil derivative negative effect on survival rate and life span of springtails. A positive effect of artificially initiated bioremediation on the soil polluted with petrol was registered already in the second month after contamination - the first live specimens were noticed in the object. Regarding the soil polluted with diesel fuel, the application of ZB-01 preparation became visible about the $12^{\text {th }}$ month after contamination, leading to further constant registration of Collembola presence until the end of the experiment, wherein in the 2012 season the number of Collembola registered in this object was similar to their number in the unpolluted soil (Fig. 3a). In the third season of research, also a beneficial effect of bioremediation was noticed in soil contaminated with engine oil, although the differences in the number of registered springtails in comparison with the object without bioremediation were not statistically proven.

Springtails occurrence was investigated depending on the degree of soil contamination with polycyclic aromatic hydrocarbons (PAHs), whose source was pollution with creosote for 50 years [27] or industry [26], however obtained results point to diversified responses. In soils containing low amounts of PAHs (5.28-80.46 $\mathrm{mg} \mathrm{kg}^{-1}$ ) positive associations of Collembola presence with PAH concentrations were registered [26], but no direct association with PAHs originating from creosote (where they occurred in a wide range from 5 to $37500 \mathrm{ppm}$ ) was noted [27]. In the latter case the authors as a more important indicate indirect influence of altering habitat of microinvertebrates and their prey, fungi and bacteria, than direct toxicity. Although these studies (similar to ours) took into account the long-term effects of soil contamination with PAHs, they were only carried out during a small period of time, i.e., within one season of 50 years after contamination. Also, research conducted by Santarufo et al. [22] points to a considerable Collembola sensitivity to changes of soil properties. While researching the effect of heavy metals, 
Table 2. Occurrence of Collembola in soil samples in individual months after soil contamination.

\begin{tabular}{|c|c|c|c|c|c|c|c|c|}
\hline \multirow{3}{*}{$\begin{array}{l}\text { Number of months } \\
\text { from the moment of soil } \\
\text { contamination }\end{array}$} & \multicolumn{8}{|c|}{ Collembola [No. of individuals / sample] } \\
\hline & \multicolumn{2}{|c|}{ Control } & \multicolumn{2}{|c|}{ Petrol } & \multicolumn{2}{|c|}{ Diesel fuel } & \multicolumn{2}{|c|}{ Engine oil } \\
\hline & OR & $\mathrm{R}$ & OR & $\mathrm{R}$ & OR & $\mathrm{R}$ & OR & $\mathrm{R}$ \\
\hline 1 & $2.00^{\mathrm{b} *}$ & $1.25^{\mathrm{b}}$ & $0.00^{\mathrm{a}}$ & $0.00^{\mathrm{a}}$ & $0.00^{\mathrm{a}}$ & $0.00^{\mathrm{a}}$ & $0.00^{\mathrm{a}}$ & $0.00^{\mathrm{a}}$ \\
\hline 2 & $0.50^{\mathrm{a}}$ & $1.75^{\mathrm{b}}$ & $0.00^{\mathrm{a}}$ & $0.25^{\mathrm{a}}$ & $0.00^{\mathrm{a}}$ & $0.00^{\mathrm{a}}$ & $0.00^{\mathrm{a}}$ & $0.00^{\mathrm{a}}$ \\
\hline 3 & $2.75^{\mathrm{b}}$ & $3.00^{\mathrm{a}}$ & $0.00^{\mathrm{a}}$ & $0.25^{\mathrm{a}}$ & $0.00^{\mathrm{a}}$ & $0.00^{\mathrm{a}}$ & $0.00^{\mathrm{a}}$ & $0.00^{\mathrm{a}}$ \\
\hline 4 & $0.25^{\mathrm{ab}}$ & $1.00^{\mathrm{b}}$ & $0.00^{\mathrm{a}}$ & $0.00^{\mathrm{a}}$ & $0.00^{\mathrm{a}}$ & $0.00^{\mathrm{a}}$ & $0.50^{\mathrm{ab}}$ & $0.00^{\mathrm{a}}$ \\
\hline 11 & $1.25^{\mathrm{bc}}$ & $1.50^{\mathrm{c}}$ & $1.50^{\mathrm{c}}$ & $0.50^{\mathrm{ab}}$ & $0.00^{\mathrm{a}}$ & $0.00^{\mathrm{a}}$ & $0.00^{\mathrm{a}}$ & $0.00^{\mathrm{a}}$ \\
\hline 12 & $4.00^{\mathrm{bc}}$ & $3.50^{\mathrm{abc}}$ & $2.25^{\mathrm{ab}}$ & $6.00^{c}$ & $0.00^{\mathrm{a}}$ & $1.50^{\mathrm{ab}}$ & $0.00^{\mathrm{a}}$ & $0.25^{\mathrm{a}}$ \\
\hline 13 & $0.50^{\mathrm{a}}$ & $0.50^{\mathrm{a}}$ & $0.75^{\mathrm{ab}}$ & $1.50^{\mathrm{b}}$ & $0.00^{\mathrm{a}}$ & $0.50^{\mathrm{a}}$ & $0.00^{\mathrm{a}}$ & $0.00^{\mathrm{a}}$ \\
\hline 14 & $0.25^{\mathrm{ab}}$ & $1.00^{\mathrm{b}}$ & $0.00^{\mathrm{a}}$ & $0.00^{\mathrm{a}}$ & $0.00^{\mathrm{a}}$ & $1.00^{\mathrm{b}}$ & $0.00^{\mathrm{a}}$ & $0.25^{\mathrm{ab}}$ \\
\hline 15 & $0.25^{\mathrm{ab}}$ & $0.50^{\mathrm{ab}}$ & $1.25^{\mathrm{b}}$ & $0.25^{\mathrm{ab}}$ & $0.00^{\mathrm{a}}$ & $0.50^{\mathrm{ab}}$ & $0.00^{\mathrm{a}}$ & $0.25^{\mathrm{ab}}$ \\
\hline 16 & $0.25^{\mathrm{a}}$ & $0.50^{\mathrm{a}}$ & $0.50^{\mathrm{a}}$ & $0.00^{\mathrm{a}}$ & $0.00^{\mathrm{a}}$ & $0.50^{\mathrm{a}}$ & $0.00^{\mathrm{a}}$ & $0.00^{\mathrm{a}}$ \\
\hline 23 & $0.50^{\mathrm{ab}}$ & $1.25^{\mathrm{b}}$ & $0.75^{\mathrm{ab}}$ & $0.25^{\mathrm{ab}}$ & $0.00^{\mathrm{a}}$ & $1.25^{\mathrm{b}}$ & $0.00^{\mathrm{a}}$ & $0.25^{\mathrm{ab}}$ \\
\hline 24 & $0.50^{\mathrm{ab}}$ & $1.75^{\mathrm{c}}$ & $0.00^{\mathrm{a}}$ & $1.50^{\mathrm{bc}}$ & $0.00^{\mathrm{a}}$ & $1.00^{\mathrm{abc}}$ & $0.00^{\mathrm{a}}$ & $0.50^{\mathrm{ab}}$ \\
\hline 25 & $0.75^{\mathrm{ab}}$ & $0.25^{\mathrm{ab}}$ & $1.00^{\mathrm{b}}$ & $0.50^{\mathrm{ab}}$ & $0.25^{\mathrm{ab}}$ & $0.25^{\mathrm{ab}}$ & $0.00^{\mathrm{a}}$ & $0.00^{\mathrm{a}}$ \\
\hline 26 & $0.00^{\mathrm{a}}$ & $0.25^{\mathrm{ab}}$ & $0.25^{\mathrm{ab}}$ & $0.00^{\mathrm{a}}$ & $0.00^{\mathrm{a}}$ & $0.75^{\mathrm{b}}$ & $0.00^{\mathrm{a}}$ & $0.25^{\mathrm{ab}}$ \\
\hline 27 & $0.25^{\mathrm{a}}$ & $0.25^{\mathrm{a}}$ & $0.25^{\mathrm{a}}$ & $0.25^{\mathrm{a}}$ & $0.00^{\mathrm{a}}$ & $0.25^{\mathrm{a}}$ & $0.00^{\mathrm{a}}$ & $0.25^{\mathrm{a}}$ \\
\hline 28 & $0.00^{\mathrm{a}}$ & $1.00^{\mathrm{a}}$ & $0.50^{\mathrm{a}}$ & $1.00^{\mathrm{a}}$ & $0.00^{\mathrm{a}}$ & $0.50^{\mathrm{a}}$ & $0.00^{\mathrm{a}}$ & $0.00^{\mathrm{a}}$ \\
\hline
\end{tabular}

*Means in lines marked with the same letters do not differ significantly according to LSD test at $\alpha=0.05$; factors contamination $\mathrm{x}$ remediation. $0 \mathrm{R}$ - series without ZB-01, R - series with ZB-01.

pesticides and fuels on Collembola populations in soil, Antoniolli et al. [38] found in laboratory conditions that in the presence of fuels (burned lubricating oil 5, 50 and $100 \mathrm{~mL} \mathrm{~kg}^{-1}$ soil and diesel oil - 5, 50 and $100 \mathrm{~mL} \mathrm{~kg}{ }^{-1}$ soil) these organisms presented an incapacity to procreate regardless of the dose applied to the soil. The presence of burned oil and diesel oil in the soil inhibited Collembolan development in the soil. During our research, starting with the moment of soil pollution and continuing for 28 months in field conditions, considerable differences in the Collembola number trapped using pitfall traps and spotted in the soil samples were registered. A clearer response to applied toxic substances was obtained through an analysis of springtails occurrence in the soil samples, which indicates the usefulness of this method in particular to assess the quality of soil contaminated with PDSs. The effect measured using pitfall traps was apparent mainly at the initial period after soil pollution, which might have resulted from a toxic effect of applied PDSs on vegetal cover. Springtails are particularly sensitive to soil shadowing, showing strong dependence on the presence and density of vegetation $[39,40]$.

A positive effect of applied ZB-01 preparation on accelerating bioremediation process in the polluted soil was registered, visible as a considerable fastening of recolonization by springtails of the soil polluted by petrol or diesel fuel. Similarly, in previous investigations the same preparation exhibited a favorable effect on enthomopathogenic nematodes occurrence [41]. On objects where biopreparation was applied, enthomopathogenic nematodes were isolated significantly faster after initial contamination than on objects where only a natural remediation process was carried out. Only few researchers focused on the influence of supported bioremediation on soil fauna. Investigations carried out so far have covered the effect of these measurements on life parameters of springtails, such as survival rate or life span $[24,28]$ and did not include the occurrence of these insects in bioremediated soil in field conditions. For instance, the application of Basispecin preparation containing Bacillus sp. 739 strain to soil to various degrees $(0,1$, 2, 5 and $10 \%$ of soil weight) polluted with Tyumen oil visibly affected springtail survival rate [24]. Already after 3 days of incubation at low oil concentrations, the survival rate of springtails in the object where Bacispecin was added was higher than in the untreated soil. At higher oil concentrations in soil, the Bacispecin effect was visible only after 180-day incubation, causing increased survival rate and life span of springtails. At the same time, this preparation effect 
a)
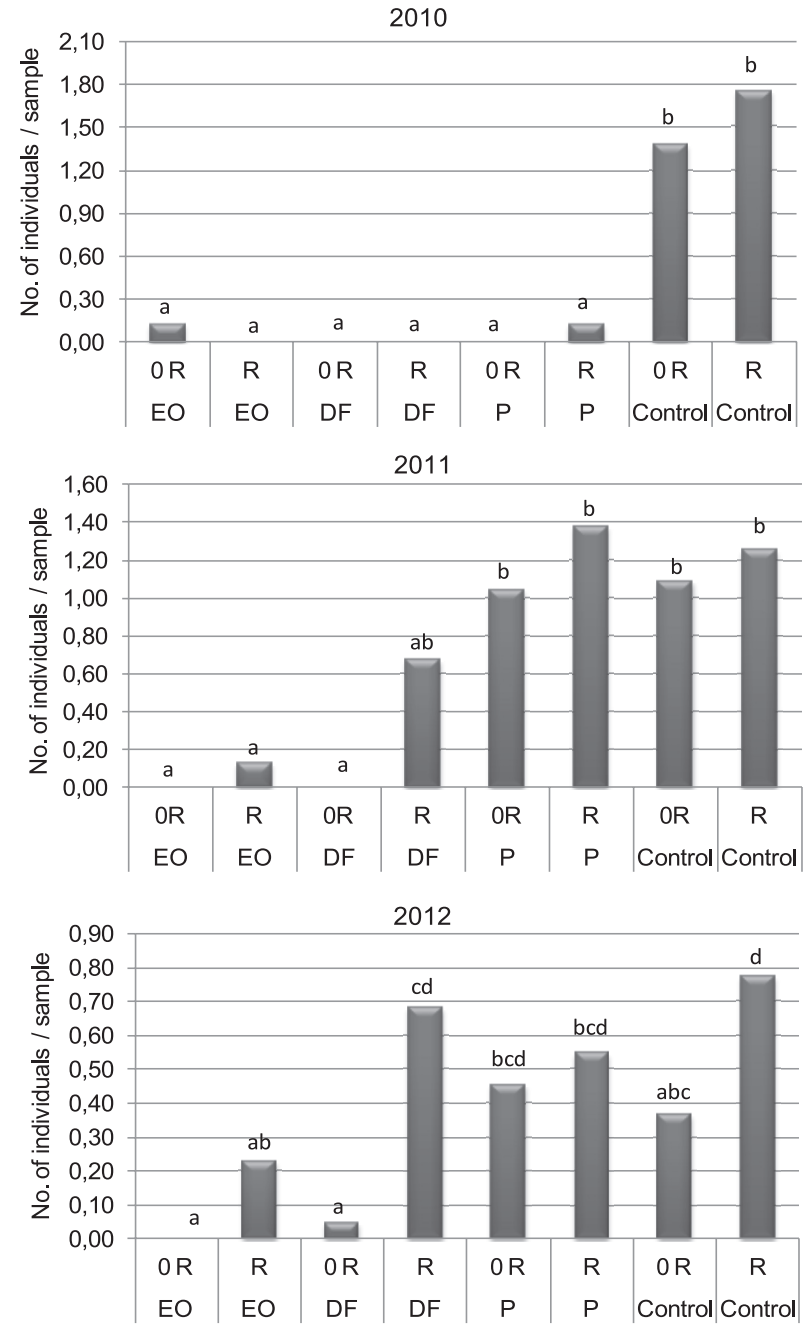

b)
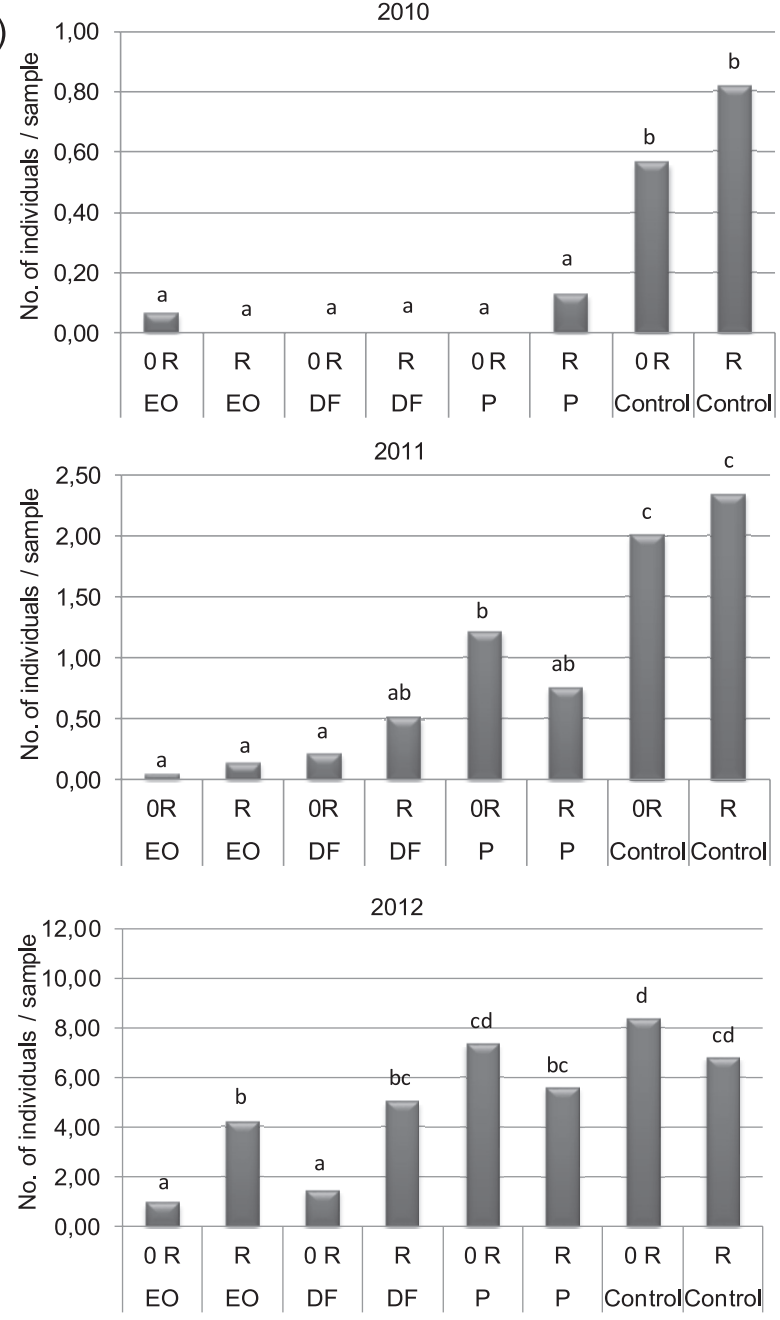

Fig. 3. Occurrence of Collembola a) and Acarina b) in soil samples mean in the years 2010, 2011, and 2012. Explanations as in Fig. 1. Means marked with the same letters do not differ significantly according to LSD test at $\alpha=0.05$; factors contamination $\mathrm{x}$ remediation.

of oil content being reduced in oil-polluted soils was demonstrated through normalization of enzymatic and microbiological parameters of the soil. In this case the biopreparation supplement caused a decrease in residual oil component by $25-40 \%$. In our investigation inoculation with ZB-01 biocenosis allowed for the degradation of PDSs present in the soil contaminated with diesel fuel and engine oil with $82.3 \%$ and $75.4 \%$ efficiency, respectively, (after 24 months) [6]. Covino et al. [28] also found that after a $60 \mathrm{~d}$ mycoaugmentation with Pseudoallescheria sp. of the clay soil historically contaminated by mid- and long-chain aliphatic hydrocarbons $(\mathrm{AH})$, a $79.7 \%$ AH reduction and a significant detoxification, inferred by a drop in mortality of Folsomia candida springtail from 90 to $24 \%$, were observed. Although the measurement of the survival and fertility of springtails is a commonly used ecotoxicological test, an analysis of the occurrence of these invertebrates in soil under natural conditions can reveal the impact of pollution more comprehensively, i.e., on the animal's habitat and their behavior strategy.
Soil pollution with oil derivatives led to a total destruction of mites in the soil samples (Table 3). Their presence was not observed for the first three months following soil contamination in any of the polluted objects. Live specimens were noticed for the first time in soil polluted with engine oil in the $4^{\text {th }}$ month after pollution. However, for most of the second growing season their presence was not found in polluted soil. In the soil contaminated with diesel fuel and petrol their presence was spotted only in the subsequent vegetation season, i.e., in the $11^{\text {th }}$ month after pollution. The population of Acarina soil started to reconstruct visibly in the soil polluted with petrol, although they reached a number similar to the control soil only in 2012 (Fig. 3b). The bioremediation process started on petrol-polluted soil caused live Acarina specimens to be spotted there already in the $3^{\text {rd }}$ month after pollution. On the other hand, in the soil polluted with diesel fuel, the process caused the number of Acarina observed in the soil samples in the 2012 season to be on a similar level as in the control soil. In the same season the number of the above-mentioned invertebrates increased considerably 
Table 3. Occurrence of Acarina in soil samples in individual months after soil contamination.

\begin{tabular}{|c|c|c|c|c|c|c|c|c|}
\hline \multirow{3}{*}{$\begin{array}{l}\text { Number of months } \\
\text { from the moment of soil } \\
\text { contamination }\end{array}$} & \multicolumn{8}{|c|}{ Acarina [No. of individuals / sample] } \\
\hline & \multicolumn{2}{|c|}{ Control } & \multicolumn{2}{|c|}{ Petrol } & \multicolumn{2}{|c|}{ Diesel fuel } & \multicolumn{2}{|c|}{ Engine oil } \\
\hline & OR & $\mathrm{R}$ & OR & $\mathrm{R}$ & OR & $\mathrm{R}$ & OR & $\mathrm{R}$ \\
\hline 1 & $0.75^{\mathrm{b} *}$ & $0.75^{\mathrm{b}}$ & $0.00^{\mathrm{a}}$ & $0.00^{\mathrm{a}}$ & $0.00^{\mathrm{a}}$ & $0.00^{\mathrm{a}}$ & $0.00^{\mathrm{a}}$ & $0.00^{\mathrm{a}}$ \\
\hline 2 & $0.50^{\mathrm{a}}$ & $1.50^{\mathrm{b}}$ & $0.00^{\mathrm{a}}$ & $0.00^{\mathrm{a}}$ & $0.00^{\mathrm{a}}$ & $0.00^{\mathrm{a}}$ & $0.00^{\mathrm{a}}$ & $0.00^{\mathrm{a}}$ \\
\hline 3 & $1.00^{\mathrm{b}}$ & $1.00^{\mathrm{b}}$ & $0.00^{\mathrm{a}}$ & $0.50^{\mathrm{ab}}$ & $0.00^{\mathrm{a}}$ & $0.00^{\mathrm{a}}$ & $0.00^{\mathrm{a}}$ & $0.00^{\mathrm{a}}$ \\
\hline 4 & $0.00^{\mathrm{a}}$ & $0.00^{\mathrm{a}}$ & $0.00^{\mathrm{a}}$ & $0.00^{\mathrm{a}}$ & $0.00^{\mathrm{a}}$ & $0.00^{\mathrm{a}}$ & $0.25^{\mathrm{a}}$ & $0.00^{\mathrm{a}}$ \\
\hline 11 & $1.25^{\mathrm{bc}}$ & $1.75^{\mathrm{c}}$ & $1.00^{\mathrm{abc}}$ & $0.00^{\mathrm{a}}$ & $0.50^{\mathrm{ab}}$ & $0.00^{\mathrm{a}}$ & $0.00^{\mathrm{a}}$ & $0.00^{\mathrm{a}}$ \\
\hline 12 & $5.00^{\mathrm{d}}$ & $4.00^{\text {cd }}$ & $2.75^{\text {bcd }}$ & $2.25^{\mathrm{abc}}$ & $0.00^{\mathrm{a}}$ & $1.00^{\mathrm{ab}}$ & $0.00^{\mathrm{a}}$ & $0.50^{\mathrm{ab}}$ \\
\hline 13 & $2.50^{\mathrm{b}}$ & $3.25^{\mathrm{b}}$ & $0.00^{\mathrm{a}}$ & $0.50^{\mathrm{a}}$ & $0.25^{\mathrm{a}}$ & $1.00^{\mathrm{a}}$ & $0.00^{\mathrm{a}}$ & $0.25^{\mathrm{a}}$ \\
\hline 14 & $1.75^{\mathrm{c}}$ & $1.25^{\mathrm{bc}}$ & $0.25^{\mathrm{ab}}$ & $0.75^{\mathrm{abc}}$ & $0.00^{\mathrm{a}}$ & $0.00^{\mathrm{a}}$ & $0.00^{\mathrm{a}}$ & $0.00^{\mathrm{a}}$ \\
\hline 15 & $1.00^{\mathrm{a}}$ & $3.50^{\mathrm{b}}$ & $2.75^{\mathrm{b}}$ & $0.50^{\mathrm{a}}$ & $0.50^{\mathrm{a}}$ & $0.50^{\mathrm{a}}$ & $0.25^{\mathrm{a}}$ & $0.00^{\mathrm{a}}$ \\
\hline 16 & $0.50^{\mathrm{a}}$ & $0.25^{\mathrm{a}}$ & $0.50^{\mathrm{a}}$ & $0.50^{\mathrm{a}}$ & $0.00^{\mathrm{a}}$ & $0.50^{\mathrm{a}}$ & $0.00^{\mathrm{a}}$ & $0.00^{\mathrm{a}}$ \\
\hline 23 & $3.50^{\mathrm{a}}$ & $1.75^{\mathrm{a}}$ & $2.00^{\mathrm{a}}$ & $3.00^{\mathrm{a}}$ & $0.50^{\mathrm{a}}$ & $3.75^{\mathrm{a}}$ & $1.75^{\mathrm{a}}$ & $1.25^{\mathrm{a}}$ \\
\hline 24 & $2.00^{\mathrm{abc}}$ & $4.25^{\mathrm{d}}$ & $2.50^{\mathrm{bcd}}$ & $3.50^{\mathrm{cd}}$ & $0.50^{\mathrm{ab}}$ & $2.75^{\mathrm{cd}}$ & $0.00^{\mathrm{a}}$ & $2.25^{\mathrm{bcd}}$ \\
\hline 25 & $2.75^{\mathrm{b}}$ & $2.00^{\mathrm{ab}}$ & $1.75^{\mathrm{ab}}$ & $0.25^{\mathrm{a}}$ & $0.00^{\mathrm{a}}$ & $0.50^{\mathrm{a}}$ & $0.00^{\mathrm{a}}$ & $0.25^{\mathrm{a}}$ \\
\hline 26 & $2.25^{\mathrm{c}}$ & $0.50^{\mathrm{ab}}$ & $0.50^{\mathrm{ab}}$ & $1.25^{\mathrm{bc}}$ & $0.25^{\mathrm{ab}}$ & $0.00^{\mathrm{a}}$ & $0.00^{\mathrm{a}}$ & $0.75^{\mathrm{ab}}$ \\
\hline 27 & $0.25^{\mathrm{a}}$ & $0.50^{\mathrm{a}}$ & $1.50^{\mathrm{b}}$ & $0.50^{\mathrm{a}}$ & $0.00^{\mathrm{a}}$ & $0.00^{\mathrm{a}}$ & $0.25^{\mathrm{a}}$ & $0.75^{\mathrm{ab}}$ \\
\hline 28 & $0.50^{\mathrm{a}}$ & $0.00^{\mathrm{a}}$ & $0.00^{\mathrm{a}}$ & $0.00^{\mathrm{a}}$ & $0.00^{\mathrm{a}}$ & $0.00^{\mathrm{a}}$ & $0.50^{\mathrm{a}}$ & $0.00^{\mathrm{a}}$ \\
\hline
\end{tabular}

*Means in lines marked with the same letters do not differ significantly according to LSD test at $\alpha=0.05$; factors contamination $\mathrm{x}$ remediation. $0 \mathrm{R}$ - series without ZB-01, R - series with ZB-01.

also in the object contaminated with engine oil after bioremediation process application (although the differences were not statistically proven).

Research of Blakely et al. [27] on the use of soil invertebrates, including Acarina as indicators of soil pollution with PAHs, revealed a reduction in the abundance of total Acarina with PAH contamination and confirmed the previous results obtained by Erstfeld and Snow-Ashbrook [26]. The authors gave two possible explanations of the observed phenomenon, i.e., pointing to a fungicial role of PAHs which may lead to elimination of microarthropod's fungal or detrital food, or to increase in bulk density due to PAH contamination, which in turn leads to a reduction of habitat space for these animals. Also, research by Garcia-Segura et al. [42] showed that Acari were the groups that were most negatively correlated to the different hydrocarbons in soil contaminated by oil spills in Mexico.

In summary, our long-term research indicates that both Collembola and Acarina are good indicators of the speed of PDS-contaminated soil self-cleaning. However, taking soil samples and their analysis in the laboratory gives a more reliable answer than the use of pitfall traps. It is worth noting that the analysis of the occurrence of soil fauna in the soil samples is a very cheap and easy to carry out method, which does not require specialized

Table 4. Mean of the Acarina and Collembola ratios (A/C) in soil samples in individual years after soil contamination.

\begin{tabular}{|c|c|c|c|c|c|c|c|c|}
\hline \multirow{3}{*}{ Year } & \multicolumn{8}{|c|}{$\mathrm{A} / \mathrm{C}$} \\
\hline & \multicolumn{2}{|c|}{ Control } & \multicolumn{2}{|c|}{ Petrol } & \multicolumn{2}{|c|}{ Diesel fuel } & \multicolumn{2}{|c|}{ Engine oil } \\
\hline & $0 \mathrm{R}^{*}$ & $\mathrm{R}$ & OR & $\mathrm{R}$ & OR & $\mathrm{R}$ & OR & $\mathrm{R}$ \\
\hline 2010 & 0.41 & 0.46 & - & 1.00 & - & - & 0.5 & - \\
\hline 2011 & 1.85 & 1.87 & 1.16 & 0.55 & - & 0.75 & - & 1 \\
\hline 2012 & 5.50 & 2.12 & 3.33 & 2.83 & 5.00 & 1.87 & - & 4.2 \\
\hline
\end{tabular}


equipment or labor-intensive rearing. It may be a useful alternative for other ecotoxicological tests in assessing PDS presence in the soil and speed of remediation process.

The $\mathrm{A} / \mathrm{C}$ ratio differed between the investigated seasons, also on the control soil. However, in the final 2012 season it revealed higher values in the objects without supported bioremediation than in the objects where the treatment was applied (Table 4). The exception was the object with the soil polluted with engine oil and subjected to bioremediation process, where the indicator was similar to control without bioremediation. The high value of the Acarina/Collembola ratio suggests high soil quality, which is associated with a decrease in Acarina species number in degraded soils. However, research conducted by Santarufo et al. [22] on soil fauna occurrence in five urban soil in Naples, Italy revealed the highest $\mathrm{A} / \mathrm{C}$ ratio value in the soil characterized by the highest content of heavy metals, such as $\mathrm{Pb}, \mathrm{Cu}$ and $\mathrm{Zn}$, which confirms previous findings of Jacomini et al. [29] showing that the indicator cannot be used in all ecosystems. The results of our research also indicate that the use of the $\mathrm{A} / \mathrm{C}$ indicator is not very suitable for assessing the condition of soil contaminated with PDSs and the speed of the self-cleaning process.

\section{Conclusions}

1. Considering the investigated PDSs, petrol revealed the shortest (about a year) negative effect on Collembola presence on the soil surface (measured by pitfall trapping), whereas it was visible for the longest time ( 2 years) for diesel fuel. Initiating a bioremediation process using ZB-01 preparation on the soil polluted with petrol (in the first year) and diesel fuel (in the second), resulting in a significant increase in Collembola activity on the soil surface; however, it limited this parameter in soil contaminated with engine oil and in the control soil (in the second and third years of the experiment).

2. Both diesel fuel and engine oil revealed a strong negative effect on the occurrence of springtails and mites in soil (measured by soil sample analysis), perceptible even after 28 months from the moment of soil pollution. At the same time, a visible positive response to applied bioremediation supported by biopreparation was registered.

3. Analysis of soil samples polluted with oil derivatives for springtail and mite presence may be a potentially useful indicator for assessing the degree of soil self-cleaning, since a perceptible response was noticed - dependent both on the oil derivative and the course on the supported bioremediation process.

\section{Acknowledgements}

Scientific publication was financed by the Ministry of Science and Higher Education of the Republic of Poland and from the funds for science in 2009-2013 as a research project (N N305 151537).

\section{Conflict of Interest}

The authors declare no conflict of interest.

\section{References}

1. UMOREN A.S., IGWENAGU C.M., EZEAKU P.I., EZENNE G.I., OBALUM S.E., GYANG B.D., IGWE C.A. Long-term effects of crude oil spillage on selected physicochemical properties including heavy metal contents of sandy tropical soil. Bulletin of Environmental Contamination and Toxicology, 102, 468, 2019.

2. RUSIN M., GOSPODAREK J., BARCZYK G., NADGORSKA-SOCHA A. Antioxidant responses of Triticum aestivum plants to petroleum-derived substances. Ecotoxicology, 27, 1353, 2018.

3. CRUZ J.M., CORROQUE N.A., MONTAGNOLI R.N., MATOS LOPES P.R., MARIN MORALES M.A., BIDOIA E.D. Comparative study of phytotoxicity and genotoxicity of soil contaminated with biodiesel, diesel fuel and petroleum. Ecotoxicology 28, 449, 2019.

4. GOSPODAREK J. Effect of oil derivative spill on epigeal mezofauna. Proceed. Ecopole, 2 (2), 309, 2008.

5. FERREIRA R.N.C., WEBER O.B., CORREIA M.E.F., BENAZZI-IKEDA E.S., SCORIZA R.N., MESQUITA A.L.M., Effects of Wastewater from Oil Exploration on Soil Mesofauna. B. Environ. Contam. Tox., 95, 777, 2015.

6. GOSPODAREK J., PETRYSZAK P., KOLOCZEK H. The effect of the bioremediation of soil contaminated with petroleum derivatives on the occurrence of epigeic and edaphic fauna. Bioremediat. J. 20 (1), 38, 2016.

7. GOSPODAREK J., RUSIN M., NADGORSKA-SOCHA A. Effect of petroleum-derived substances and their bioremediation on Triticum aestivum L. growth and chemical composition. Pol. J. Environ. Stud., 28, 2131, 2019.

8. RUSIN M., GOSPODAREK J., NADGÓRSKA-SOCHA A., BARCZYK G. Effect of petroleum-derived substances on life history traits of black bean aphid (Aphis fabae Scop.) and on the growth and chemical composition of broad bean. Ecotoxicology 26, 308, 2017.

9. GOSPODAREK J., NADGORSKA-SOCHA A. Chemical composition of broad beans (Vicia faba L.) and development parameters of black bean aphid (Aphis fabae Scop.) under conditions of soil contamination with oil derivatives. J. Elem., 21, 1359, 2016.

10. RUSIN M., GOSPODAREK J., NADGÓRSKA-SOCHA A., BARCZYK G., BOLIGŁOWA E., DABIOCH M. Effect of petroleum-derived substances on life history traits of bird cherry-oat aphid (Rhopalosiphum padi L.) and on the growth and chemical composition of winter wheat. Environ. Sci. Pollut. Res., 25 (2), $27000,2018$. 
11. GOSPODAREK, J., PETRYSZAK, P., KOŁOCZEK, H., RUSIN, M. The effect of soil pollution with petroleumderived substances on Porcellio scaber Latr. (Crustacea, Isopoda). Environ. Monit. Assess. 191, 38, 2019.

12. WOLFF D.C., CRYDER Z., GAN J. Soil bacterial community dynamics following surfactant addition and bioaugmentation in pyrene-contaminated soils. Chemosphere 231, 93, 2019.

13. SZULC A., AMBROŻEWICZ D., SYDOW M., ŁAWNICZAK Ł., PIOTROWSKA-CYPLIK A., MARECIK R., CHRZANOWSKI $Ł$. The influence of bioaugmentation and biosurfactant addition on bioremediation efficiency of diesel-oil contaminated soil: Feasibility during field studies. J. Environ. Manage., 132, 121, 2014

14. KAUPPI S., SINKKONEN A., ROMANTSCHUK M. Enhancing bioremediation of diesel-fuel-contaminated soil in a boreal climate: Comparison of biostimulation and bioaugmentation. Int. Biodeter. Biodegr., 65 (2), 359, 2011.

15. CAMACHO-MONTEALEGRE C.M., RODRIGUES E.M., TOTOLA M.R. Microbial diversity and bioremediation of rhizospheric soils from Trindade Island - Brazil. J. Environ. Manage., 236, 358, 2019.

16. MA Y., LI X., MAO H., WANG B., WANG P. Remediation of hydrocarbon-heavy metal co-contaminated soil by electrokinetics combined with biostimulation. Chem. Eng. J., 353, 410, 2018.

17. SAKSHI SINGH S.K., HARITASH A.K. Polycyclic aromatic hydrocarbons: soil pollution and remediation. Int. J. Environ. Sci. Te. 16, 6489, 2019.

18. VINCENT Q., LEYVAL C., BEGUIRISTAIN T., AUCLERC A. Functional structure and composition of Collembola and soil macrofauna communities depend on abiotic parameters in derelict soils. Appl. Soil Ecol., 130, 259, 2018.

19. SANTAMARIA J.M., MORAZA M.L., ELUSTONDO D., BAQUERO E., JORDANA R., LASHERAS E., BERMEJO R., ARINO A.H., Diversity of Acari and Collembola along a pollution gradient in soils of a prepyrenean forest ecosystem. Environmental Engineering and Management Journal, 11, 1159, 2012.

20. SANTORUFO L., CORTET J., ARENA C., GOUDON R., RAKOTO A., MOREL J.L., MAISTO G. An assessment of the influence of the urban environment on collembolan communities in soils using taxonomy- and trait-based approaches. Applied Soil Ecology 78, 48, 2014.

21. SUN X.-B., LI Y.-C. Impact of heavy metal pollution on soil animal communities in abandoned coal mine area in Huainan City, Anhui Province. Shengtaixue Zazhi 33, 408, 2014.

22. SANTARUFO L., VAN GESTEL C.A.M., ROCCO A., MAISTO G. Soil invertebrates as bioindicators of urban soil quality. Environ. Pollut., 161, 57, 2012.

23. KHALIL M.A., JANSSENS T.K., BERG M., VAN STRAALEN N.M. Identification of metal-responsive oribatid mites in a comparative survey of polluted soils. Pedobiologia, 52, 207, 2009.

24. KIREEVA N.A., KHANISLAMOVA G.M., TARASENKO E.M. Biological testing of oil-polluted and reclaimed soils based on the survival of springtails (Collembola). Russ. J. Ecol., 36, 361, 2005.

25. KOLTOWSKI M., OLESZCZUK P. Effect of activated carbon or biochars on toxicity of different soils contaminated by mixture of native polycyclic aromatic hydrocarbons and heavy metals. Environ. Toxicol. Chem., 35, 1321, 2016.
26. ERSTFELD K.M., SNOW-ASHBROOK J. Effects of chronic low-level PAH contamination on soil invertebrate communities. Chemosphere, 39, 2117, 1999.

27. BLAKELY J.K., NEHER D.A., SPONGBERG A.L. Soil invertebrate and microbial communities, and decomposition as indicators of polycyclic aromatic hydrocarbon contamination. Appl. Soil Ecol., 21, 71, 2002.

28. COVINO S., D’ANNIBALE A., STAZI S.R., CAJTHAML T., CVANCAROVA M., STELlA T., PETRUCCIOLI M. Assessment of degradation potential of aliphatic hydrocarbons by autochthonous filamentous fungi from a historically polluted clay soil. Sci. Total Environ., 505, $545,2015$.

29. JACOMINI C., NAPPI P., SBRILLI G., MANCINI L. Indicatori ed Indici Ecotossicologici e Biologici Applicati al Suolo: Stato Dell'arte. Agenzia Nazionale per la Protezione dell'Ambiente, (ANPA). RTI CTN SSC, 3, 29, 2000.

30. RUSIN M., GOSPODAREK J. The Occurrence of Springtails (Collembola) Andspiders (Araneae) as an Effectiveness Indicator of Bioremediation of Soil Contaminated by Petroleum-Derived Substances. Int. J. Environ. Res. 10, 449, 2016.

31. ERRINGTON I., KING C.K., HOULAHAN S., GEORGE S.C., MICHIE A., HOSE G.C. The influence of vegetation and soil properties on springtail communities in a diesel-contaminated soil. Sci. Total Environ., 619, 1098, 2018.

32. MOONEY T.J., WASLEY J., RAYMOND B., ANDREW N.R., KING C.K. Response of the Native Springtail Parisotoma insularis to Diesel Fuel-Contaminated Soils Under Field-Realistic Exposure Conditions at Subantarctic Macquarie Island. Integr. Environ. Asses., 15, $565,2019$.

33. GOSPODAREK J., RUSIN M., NADGÓRSKA-SOCHA A. Effect of petroleum-derived substances and their bioremediation on Triticum aestivum L. growth and chemical composition. Pol. J. Environ. Stud. 28 (4), 2131, 2019.

34. QUERNER P., BRUCKNER A. Combining pitfall traps and soil samples to collect Collembola for site scale biodiversity assessments. Appl. Soil Ecol., 45, 293, 2010.

35. ISO 23611-2. Soil Quality - Sampling of Soil Invertebrates - Part 2: Sampling and Extraction of Micro-Arthropods (Collembola and Acarina). Geneva: ISO, 2006.

36. GOSPODAREK J. The effect of oil derivative leak on the course of dynamics of Collembola, Arachnida, Staphylinidae and Formicidae occurrence. In: Pierwiastki, środowisko i życie człowieka, pod red. K. Pasternaka. Lublin, 57, 2009.

37. URBANOVICOVA V., MIKLISOVA D., KOVAC L.U. Forest disturbance enhanced the activity of epedaphic collembola in windthrown stands of the High Tatra mountains. J. Mt. Sci. 11, 449, 2014.

38. ANTONIOLLI Z.I., REDIN M., DE SOUZA E.L., POCOJESKI E. Heavy metal, pesticides and fuels: effect in the population of collembola in the soil. Cienc. Rural, $\mathbf{4 3}$ (6), 992, 2013.

39. GONZALEZ E., SALVO A., VALLADARES G. Natural vegetation cover in the landscape and edge effects: differential responses of insect orders in a fragmented forest. Insect Sci., 24, 891, 2017.

40. WASLEY J., MOONEY T.J., KING C.K. Soil invertebrate community change over fuel-contaminated sites on a 
subantarctic island: An ecological field-based line of evidence for site risk assessment. Integr. Environ. Asses. 12, 306, 2016.

41. ROPEK D., GOSPODAREK J. Effect of soil pollution with oil derivatives on the occurrence of entomopathogenic nematodes. Ecol. Chem. Eng. A, 20 (2), 157, 2013.
42. GARCIA-SEGURA D., CASTILLO-MURRIETA I.M., MARTINEZ-RABELO F., GOMEZ-ANAYA A., RODRIGUEZ-CAMPOS J., HERNANDEZCASTELLANOS B., CONTRERAS-RAMOS S.M., BAROIS I. Macrofauna and mesofauna from soil contaminated by oil extraction. Geoderma 332, 180-189, 2018. 
